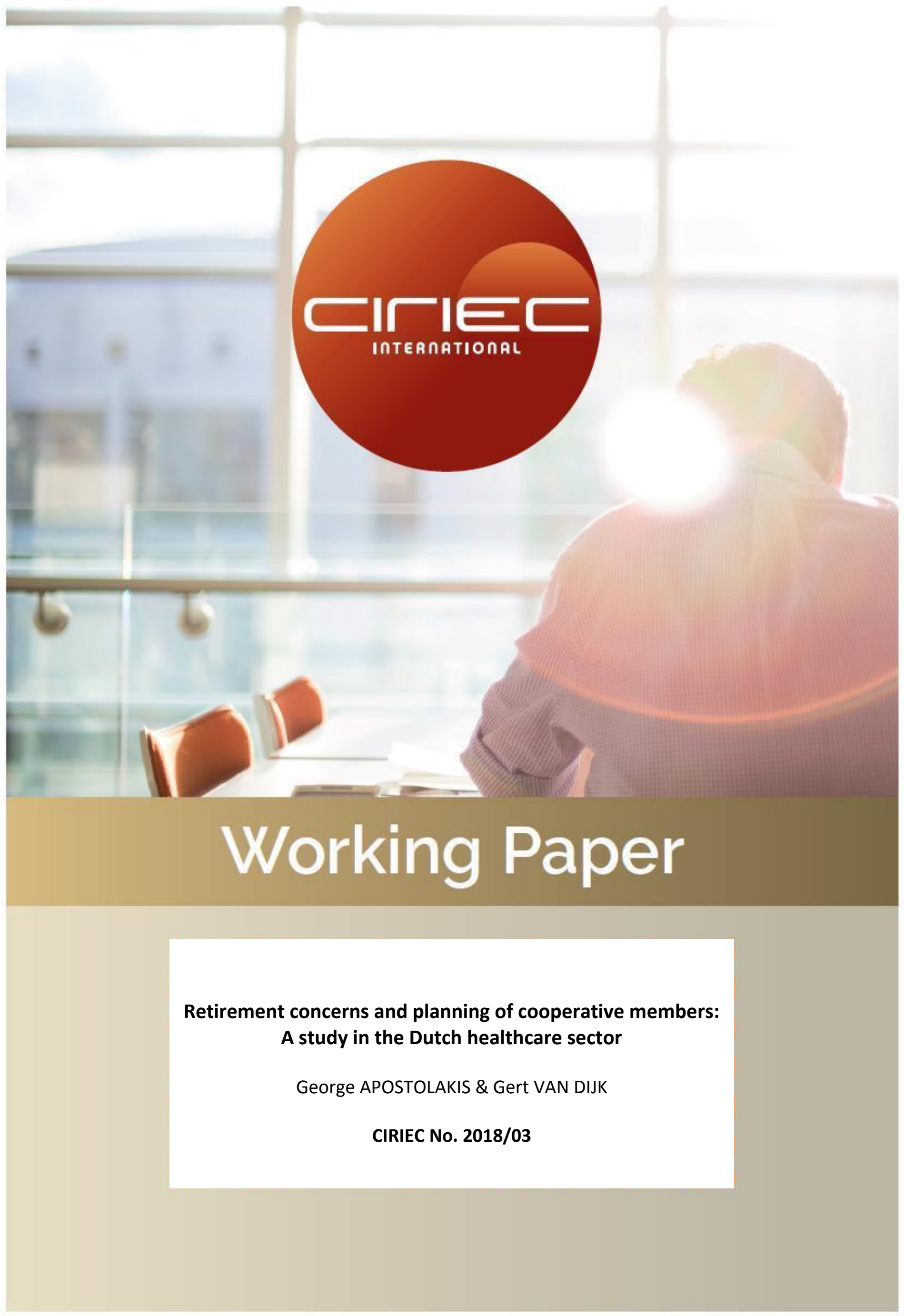


CIRIEC activities, publications and researches are realised with the support of

Les activités, publications et recherches du CIRIEC sont réalisées avec le soutien de
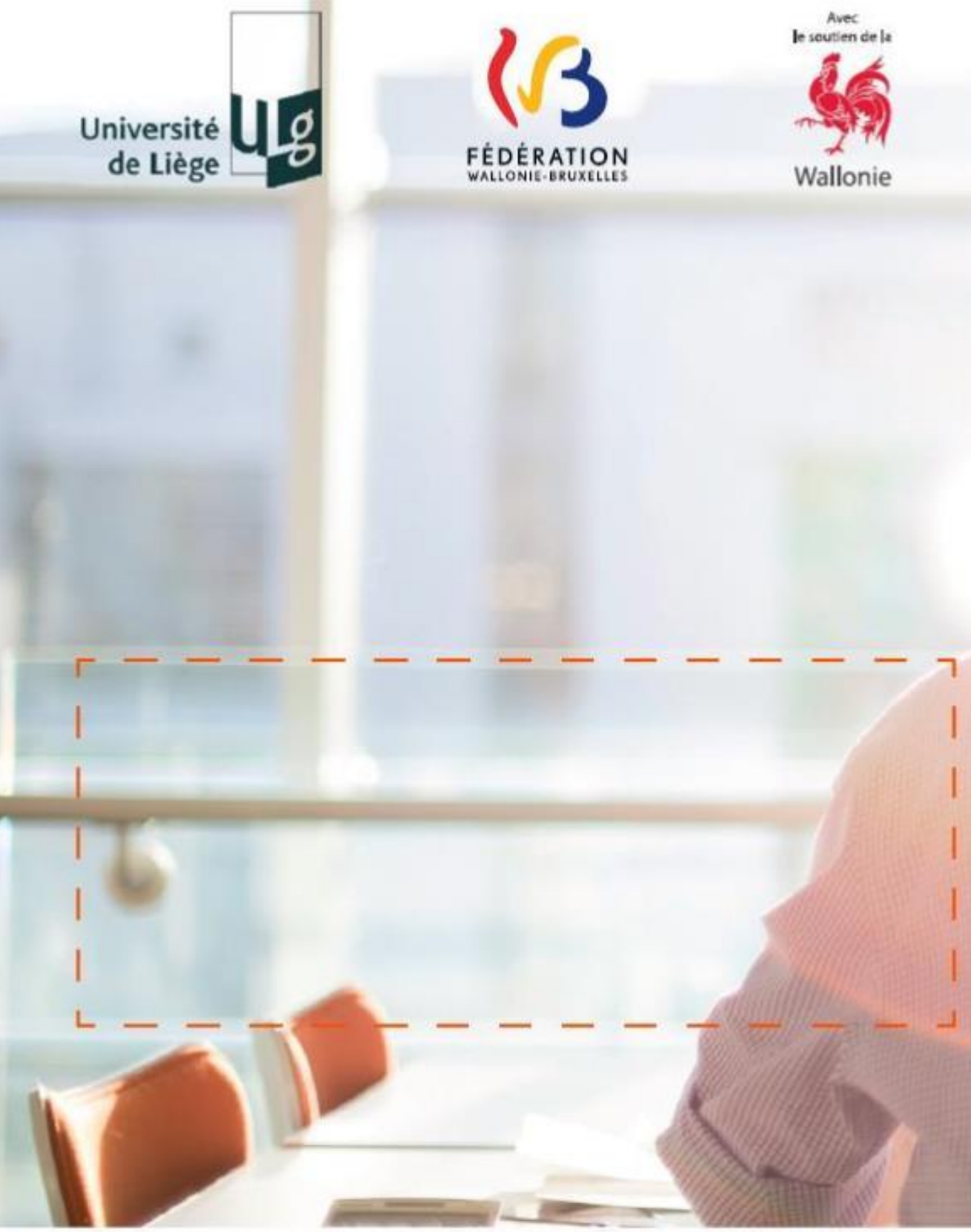


\title{
Retirement concerns and planning of cooperative members: A study in the Dutch healthcare sector
}

\author{
George Apostolakis ${ }^{*}$ and Gert Van Dijk ${ }^{* *}$
}

Working paper CIRIEC No. 2018/03

\footnotetext{
Nyenrode Business Universiteit (Straatweg 25, 3621 BG Breukelen P.O. Box 130, 3620 AC, Breukelen, The Netherlands, Phone: +31 346291560 - Fax: +31 346291250); Department of Economics, University of Crete (Rethymno Campus, 74100 Rethymno, Greece) (Corresponding author: g.apostolakis@nyenrode.nl).

** Department of Social Sciences, Wageningen University, Wageningen, The Netherlands; TIAS School for Business and Society, Tilburg University, Tilburg, The Netherlands; Centre for Entrepreneurship, Governance \& Stewardship, Nyenrode Business Universiteit, Breukelen, The Netherlands.
} 


\section{Abstract}

Retirement planning is a key component in achieving retirement goals and fulfilling retirement expectations. Although several socio-economic and psychological factors associated with retirement planning have been reported in the literature, little is known about the influence that specific retirement-related issues have on retirement planning. In this paper, we examine the influence of five retirement concerns - the individual's financial situation, living situation, care provision, health condition, and loneliness - on retirement planning. Our dataset is derived from a 2010 web-based survey in the care and wellbeing sector in the Netherlands.

Keywords: healthcare; retirement planning; uncertainty

JEL Codes: D12; D60; G23; I31; J26 


\section{Introduction}

Several socio-economic and psychological factors that relate to individuals' levels of concern and that influence retirement planning decisions have been reported in the literature, including income and wealth levels, financial literacy, and future time perspective. Other factors related to uncertainty that have been less extensively examined in the literature include a variety of concerns, such as those involving living standards, care provision, future health condition, social inclusion, and loneliness. Owen and Wu (2007) posit that an unstable financial environment is likely to increase the level of retirement-related concerns. Knoll (2010) further argues that the recent economic turmoil has increased people's concerns about their retirement savings. However, little research has focused on the impact of retirement concerns on retirement planning and preferences. This study aims to fill this gap by addressing whether and to what extent retirement concerns are associated with retirement planning.

In this study, we test whether retirement concerns have an influence on retirement preferences and on retirement planning. On the one hand, planning ordinarily acts as an alleviative mechanism, which decreases concerns about future outcomes. On the other hand, a high level of concern increases the propensity toward planning. However, we stress that we do not attempt to establish a causal relationship between retirement concerns and planning. We seek to investigate the relationship between retirement concerns, the perception of an ideal post-retirement situation, and the likelihood of someone engaging in retirement planning.

In this study, we make several contributions to the literature on retirement planning (Hershey, Jacobs-Lawson, McArdle, and Hamagami, 2007; Van Rooij, Lusardi, and Alessie, 2011, 2012). First, we examine the impact of retirement concerns on the propensity to plan for retirement based on a sample of cooperative members involved in the Dutch healthcare sector. Second, we examine individual preferences regarding ideal post-retirement situations. In particular, we focus on perceptions of the ideal financial situation and the impact of retirement concerns on such perceptions. In this study, we employ concerns regarding an individual's post-retirement financial situation, living situation, care provision, health condition, and loneliness. This study thus aims to further the understanding of these five factors and their role in retirement planning and in shaping individuals' post-retirement preferences. 


\section{Data and Methods}

\subsection{Sample}

Our data are derived from a 2010 survey on attitudes regarding postretirement life preferences. Members received an invitation to participate in an internet-based study via the member newsletter in October 2010. From the 13,926 collected questionnaires, and given that this study focuses on retirement planning for members aged between 45-65, we randomly took a sample of 1,288 members.

In all, 825 of the respondents (66\%) were women, and 436 (34\%) were men. A high percentage of female respondents is expected because the health care sector in the Netherlands is dominated by women. ${ }^{1}$ Although this sample of respondents is not representative of the entire Dutch population, studying the attitudes and preferences of those who work in the care sector and who have more first-hand knowledge of the difficulties of aging with respect to postretirement issues may lead to interesting insights. In terms of education, nearly half of the participants (47\%) hold a degree from an institution of higher education (HBO, University). Finally, $81 \%$ of the participants own a house; $41 \%$ have worked over 30 years in the healthcare sector; and $41 \%$ have been working more than 32 hours per week.

\subsection{Measures}

Dependent variables. The survey instrument included the question, "Do you ever think about your retirement?" Possible responses included "a lot," "regularly," "sometimes," and "(almost) never." Approximately $43 \%$ of the members indicated that they thought about retirement "regularly," whereas $36 \%$ indicated that they did so "sometimes." Approximately $17 \%$ of the respondents reported that they thought about retirement "a lot," and only 5\% indicated that they "almost never" did so. The low levels of thinking about retirement might be influenced by the limited involvement that the Dutch pension system requires from pension beneficiaries (Hershey et al., 2007; Van Rooij et al., 2011). Van Rooij et al. (2011) find that, in a different type of pension system, such as that in the US, respondents are likely to think about their retirement substantially more often than respondents under the Dutch pension system.

\footnotetext{
${ }^{1}$ http://ec.europa.eu/health/workforce/docs/staff working doc healthcare workforce en. pdf
} 
Independent variables. The survey included a question regarding the subjective level of concern about retirement based on five important features of postretirement life conditions. The survey participants rated five statements (from 1 = "not worried at all" to 5 = "very worried") regarding concerns about financial situations, living situations, care provision, health conditions, and loneliness. With respect to the five retirement concerns, Table 1 illustrates that, on average, respondents were most concerned about care provision and their financial situation, followed closely by concerns regarding their health, and that living concerns and loneliness were the least important concerns among the five.

Next, the five different aspects of retirement concerns were combined into a single scale to measure the aggregate level of retirement concerns. To check whether the five items measured could be used as a single measure of retirement concerns, we submitted the data to exploratory factor analysis ${ }^{2}$ and estimated Cronbach's alpha for scale reliability (Cronbach's alpha $=0.74$ ). Importantly, we do not mean to imply that the different aspects of retirement concerns are one-dimensional by combining the variables that represent these aspects into a single retirement concern measure. Nonetheless, the positive pairwise correlations among retirement concerns suggest some underlying common variance.

Control variables. Finally, we controlled for a number of socio-demographic variables that have been commonly found to influence attitudes toward retirement in the literature (Van Rooij, Kool, and Prast, 2007; Hershey, JacobsLawson, et al., 2007; Hershey, Henkens, and Van Dalen, 2010). In particular, we controlled for gender (male $=1$, and female $=0$ ) and level of education (lower, medium, higher level of education). Moreover, as home ownership may be considered an important asset, we used it as a proxy of housing wealth. Therefore, we used a dummy for living conditions (renter, homeowner, nonhomeowner, or other). Finally, we controlled for the number of working years (working for less than five, 5-10, 11-20, 21-30 years, and more than 30 years) and working hours (working less than $8,8-15,16-32$ hours, or $>32$ hours).

\footnotetext{
${ }^{2}$ The five items load onto a single factor. The Kaiser-Meyer-Olkin (KMO) measure is 0.73. The $p$ value for Bartlett's test of sphericity is 0 .
} 
Table 1 - Means, standard deviations, and coding of variables

\begin{tabular}{|c|c|c|c|c|}
\hline Variables & Mean & $\begin{array}{l}\text { Stand. } \\
\text { Dev. }\end{array}$ & Coding & Description \\
\hline \multicolumn{5}{|l|}{ Dependent variables } \\
\hline Retirement planning & & & & $\begin{array}{l}\text { Four-category variable ranging from: yes, a lot, yes, } \\
\text { regularly, yes, sometimes, and no, (almost) never }\end{array}$ \\
\hline yes, a lot & 0.1646 & 0.3710 & $0-1$ & \\
\hline yes, regularly & 0.4293 & 0.4952 & $0-1$ & \\
\hline yes, sometimes & 0.3587 & 0.4798 & $0-1$ & \\
\hline no, (almost) never & 0.0474 & 0.2125 & $0-1$ & \\
\hline $\begin{array}{l}\text { Retirement planning (dummy } \\
\text { variable) }\end{array}$ & 0.9526 & 0.2125 & $0-1$ & $\begin{array}{l}\text { Dummy variable coded } 1 \text { if the respondent thought } \\
\text { about retirement }\end{array}$ \\
\hline \multicolumn{5}{|l|}{ Explanatory variables } \\
\hline \multicolumn{5}{|l|}{ Retirement concerns } \\
\hline Financial concerns & 3.2469 & 0.9726 & $1-5$ & $\begin{array}{l}\text { One-item scale variable ranging from } 1 \text { (not worried } \\
\text { at all) to } 5 \text { (very worried) }\end{array}$ \\
\hline Living concerns & 2.3160 & 0.9322 & $1-5$ & $\begin{array}{l}\text { One-item scale variable ranging from } 1 \text { (not worried } \\
\text { at all) to } 5 \text { (very worried) }\end{array}$ \\
\hline Care concerns & 3.2469 & 1.0495 & $1-5$ & $\begin{array}{l}\text { One-item scale variable ranging from } 1 \text { (not worried } \\
\text { at all) to } 5 \text { (very worried) }\end{array}$ \\
\hline Health concerns & 2.9658 & 0.9405 & $1-5$ & $\begin{array}{l}\text { One-item scale variable ranging from } 1 \text { (not worried } \\
\text { at all) to } 5 \text { (very worried) }\end{array}$ \\
\hline Loneliness & 2.2710 & 0.9280 & $1-5$ & $\begin{array}{l}\text { One-item scale variable ranging from } 1 \text { (not worried } \\
\text { at all) to } 5 \text { (very worried) }\end{array}$ \\
\hline Aggregate retirement concerns & 2.8093 & 0.6785 & $1-5$ & $\begin{array}{l}\text { Five-item scale variable ranging from } 1 \text { (not worried } \\
\text { at all) to } 5 \text { (very worried). Cronbach's alpha }= \\
0.7436 .\end{array}$ \\
\hline \multicolumn{5}{|l|}{ Control variables } \\
\hline Male vs female & 0.3385 & 0.4734 & $0-1$ & Dummy variable coded 1 if male \\
\hline Renter vs. homeowner & 0.1786 & 0.3831 & $0-1$ & Dummy variable coded 1 if renter \\
\hline $\begin{array}{l}\text { Non-homeowner vs. } \\
\text { homeowner }\end{array}$ & 0.0054 & 0.0735 & $0-1$ & Dummy variable coded 1 if no-homeowner \\
\hline $\begin{array}{l}\text { Other home situation vs. } \\
\text { homeowner }\end{array}$ & 0.0101 & 0.1000 & $0-1$ & Dummy variable coded 1 if other \\
\hline $\begin{array}{l}\text { Lower vs. higher education } \\
\text { level (HBO-WO) }\end{array}$ & 0.1211 & 0.3264 & $0-1$ & Dummy variable coded 1 if lower education \\
\hline $\begin{array}{l}\text { Middle vs. higher education } \\
\text { level (HBO-WO) }\end{array}$ & 0.4092 & 0.4919 & $0-1$ & Dummy variable coded 1 if middle education \\
\hline Working years, $<5$ vs. $>30$ & 0.0543 & 0.2268 & $0-1$ & Dummy variable coded 1 if working years $<5$ \\
\hline Working years, $5-10 \mathrm{vs.}>30$ & 0.0691 & 0.2537 & $0-1$ & Dummy variable coded 1 if working years 5-10 \\
\hline Working years, $11-20$ vs. > 30 & 0.1964 & 0.3975 & $0-1$ & Dummy variable coded 1 if working years $12-20$ \\
\hline Working years, $21-30$ vs. > 30 & 0.2725 & 0.4454 & $0-1$ & Dummy variable coded 1 if working years 21-30 \\
\hline Working hours, $<8$ vs. $>32$ & 0.0124 & 0.1108 & $0-1$ & Dummy variable coded 1 if working hours $<8$ \\
\hline
\end{tabular}

Random sample of 1,288 respondents. 


\section{Results}

\subsection{Retirement Planning}

Table 2 introduces the results of the baseline retirement planning model in which financial concerns and the control variables are included in the ordered logistic regression. Interpreting our findings, men are 3.5\% and 5.5\% more likely than women to think their retirement "regularly" or "more often", respectively. Financial concerns and health concerns significantly influence the likelihood of retirement planning: members with greater financial and health concerns are more likely to think their retirement regularly or more often. In Panel $B$, the results show that the aggregate measure for retirement concern is significantly associated with an increased propensity to plan for retirement for those who think very often and regularly their retirement. More precisely, those with higher retirement concerns are $9 \%$ more likely to think retirement very often.

Figure 1 depicts the probability of retirement planning by gender and retirement concerns. The 2 lines that start at the top left show that the probability of thinking retirement sometimes is around $55 \%$ for those who do not concern at all and less than $20 \%$ for those who concern very much. Conversely, the 2 lines that start at the bottom left show that those who do not concern at all, hardly think about their retirement very much, and those who concern very much reach less than $10 \%$. In both these cases, women are more likely to plan their retirement than men. 
Table 2 - Ordered logistic results of retirement planning

\begin{tabular}{|c|c|c|c|c|}
\hline Retirement planning & 1 & 2 & 3 & 4 \\
\hline Explanatory variables & No almost never & Yes, sometimes & Yes, regularly & Yes, very often \\
\hline \multicolumn{5}{|l|}{ Panel A } \\
\hline \multirow[t]{2}{*}{ Financial concerns } & $-0.0233 * * *$ & $-0.0885 * * *$ & $0.0463 * * *$ & $0.0655 * * *$ \\
\hline & $(-5.5055)$ & $(-8.5719)$ & $(7.2987)$ & $(7.7275)$ \\
\hline \multirow[t]{2}{*}{ Living concerns } & -0.0040 & -0.0151 & 0.0079 & 0.0112 \\
\hline & $(-1.2174)$ & $(-1.2310)$ & $(1.2220)$ & $(1.2327)$ \\
\hline \multirow[t]{2}{*}{ Care concerns } & 0.0040 & 0.0151 & -0.0079 & -0.0112 \\
\hline & $(1.4190)$ & $(1.4072)$ & $(-1.4177)$ & $(-1.4042)$ \\
\hline \multirow[t]{2}{*}{ Health concerns } & $-0.0114 * * *$ & $-0.0432 * * *$ & $0.0226 * * *$ & $0.0320 * * *$ \\
\hline & $(-3.5555)$ & $(-3.8813)$ & $(3.7351)$ & $(3.8617)$ \\
\hline \multirow[t]{2}{*}{ Loneliness } & 0.0035 & 0.0134 & -0.0070 & -0.0099 \\
\hline & $(1.0468)$ & $(1.0601)$ & $(-1.0511)$ & $(-1.0618)$ \\
\hline \multirow[t]{2}{*}{ Male } & $-0.0176^{* * *}$ & $-0.0732 * * *$ & $0.0353 * * *$ & $0.0555 * * *$ \\
\hline & $(-2.9981)$ & $(-2.8869)$ & $(3.0527)$ & $(2.8106)$ \\
\hline \multirow[t]{2}{*}{ Renter vs. homeowner } & 0.0051 & 0.0186 & -0.0102 & -0.0135 \\
\hline & $(0.7142)$ & $(0.7417)$ & $(-0.7107)$ & $(-0.7556)$ \\
\hline \multirow[t]{2}{*}{ Non-homeowner vs. homeowner } & -0.0126 & -0.0546 & 0.0229 & 0.0442 \\
\hline & $(-0.7214)$ & $(-0.6358)$ & $(0.8475)$ & $(0.5800)$ \\
\hline \multirow[t]{2}{*}{ Other home situation vs. homeowner } & 0.0009 & 0.0034 & -0.0018 & -0.0025 \\
\hline & $(0.0249)$ & $(0.0251)$ & $(-0.0248)$ & $(-0.0253)$ \\
\hline \multirow[t]{2}{*}{ Lower vs. higher education level } & -0.01027 & -0.03925 & 0.01992 & 0.02960 \\
\hline & $(-1.281)$ & $(-1.261)$ & $(1.356)$ & $(1.208)$ \\
\hline \multirow[t]{2}{*}{ Middle vs. higher education level } & -0.0075 & -0.02783 & 0.01472 & 0.02061 \\
\hline & $(-1.279)$ & $(-1.306)$ & $(1.305)$ & $(1.296)$ \\
\hline \multirow[t]{2}{*}{ Working years, $<5$ vs. $>30$} & $0.0386 * *$ & $0.1501 * * *$ & $-0.0814 * *$ & $-0.1073 * * *$ \\
\hline & $(2.3555)$ & $(3.5410)$ & $(-2.4773)$ & $(-4.0621)$ \\
\hline \multirow[t]{2}{*}{ Working years, 5-10 vs. > 30} & $0.0432 * * *$ & $0.1616 * * *$ & $-0.0910 * * *$ & $-0.1137 * * *$ \\
\hline & $(2.9850)$ & $(4.5655)$ & $(-3.2171)$ & $(-5.1404)$ \\
\hline \multirow[t]{2}{*}{ Working years, $11-20$ vs. $>30$} & $0.0339 * * *$ & $0.1374 * * *$ & $-0.0713 * * *$ & $-0.1000 * * *$ \\
\hline & $(3.8836)$ & $(5.1341)$ & $(-3.9878)$ & $(-5.4813)$ \\
\hline \multirow[t]{2}{*}{ Working years, $21-30$ vs. > 30} & $0.0204 * * *$ & $0.0938 * * *$ & $-0.0412 * * *$ & $-0.0729 * * *$ \\
\hline & $(3.4171)$ & $(4.0468)$ & $(-3.4103)$ & $(-4.1537)$ \\
\hline \multirow[t]{2}{*}{ Working hours, $<8$ vs. $>32$} & -0.0179 & -0.1053 & 0.0168 & 0.1063 \\
\hline & $(-1.2011)$ & $(-0.9945)$ & $(1.1358)$ & $(0.8025)$ \\
\hline \multirow[t]{2}{*}{ Working hours, $8-15$ vs. $>32$} & $0.0259 *$ & $0.0951 * *$ & $-0.0547 *$ & $-0.0663 * *$ \\
\hline & $(1.7845)$ & $(2.1823)$ & $(-1.8223)$ & $(-2.3483)$ \\
\hline \multirow[t]{2}{*}{ Working hours, $16-32$ vs. > 32} & $0.0145^{* *}$ & $0.05919 * *$ & $-0.03019 * *$ & $-0.04351 * *$ \\
\hline & $(2.355)$ & $(2.361)$ & $(-2.379)$ & $(-2.341)$ \\
\hline Observations & 1,288 & & & \\
\hline Pseudo R-squared & 0.0627 & & & \\
\hline Wald Chi-squared & 162.44 & & & \\
\hline
\end{tabular}


Panel B

\begin{tabular}{|c|c|c|c|c|}
\hline Aggregate retirement concerns & $\begin{array}{l}-0.0274 * * * \\
(-5.0120)\end{array}$ & $\begin{array}{l}-0.1083 * * * \\
(-7.3215)\end{array}$ & $\begin{array}{l}0.0565 * * * \\
(6.2757)\end{array}$ & $\begin{array}{l}0.0792 * * * \\
(6.8073)\end{array}$ \\
\hline Male & $\begin{array}{l}-0.0209 * * * \\
(-3.5912)\end{array}$ & $\begin{array}{l}-0.0922 * * * \\
(-3.5623)\end{array}$ & $\begin{array}{l}0.0436 * * * \\
(3.7862)\end{array}$ & $\begin{array}{l}0.0695 * * * \\
(3.4031)\end{array}$ \\
\hline Renter vs. homeowner & $\begin{array}{l}-0.0012 \\
(-0.1914)\end{array}$ & $\begin{array}{l}-0.0050 \\
(-0.1900)\end{array}$ & $\begin{array}{l}0.0026 \\
(0.1924)\end{array}$ & $\begin{array}{l}0.0036 \\
(0.1889)\end{array}$ \\
\hline Non-homeowner vs. homeowner & $\begin{array}{l}-0.0029 \\
(-0.1481)\end{array}$ & $\begin{array}{l}-0.0119 \\
(-0.1439)\end{array}$ & $\begin{array}{l}0.0059 \\
(0.1504)\end{array}$ & $\begin{array}{l}0.0088 \\
(0.1412)\end{array}$ \\
\hline Other home situation vs. homeowner & $\begin{array}{l}-0.0119 \\
(-0.4415)\end{array}$ & $\begin{array}{l}-0.0535 \\
(-0.3897)\end{array}$ & $\begin{array}{l}0.0226 \\
(0.5188)\end{array}$ & $\begin{array}{l}0.0429 \\
(0.3547)\end{array}$ \\
\hline Lower vs. higher education level & $\begin{array}{l}-0.008 \\
(-1.032)\end{array}$ & $\begin{array}{l}-0.03367 \\
(-1.016)\end{array}$ & $\begin{array}{l}0.01715 \\
(1.083)\end{array}$ & $\begin{array}{l}0.02502 \\
(0.979)\end{array}$ \\
\hline Middle vs. higher education level & $\begin{array}{l}-0.006 \\
(-1.104)\end{array}$ & $\begin{array}{l}-0.02483 \\
(-1.125)\end{array}$ & $\begin{array}{l}0.01305 \\
(1.122)\end{array}$ & $\begin{array}{l}0.01817 \\
(1.119)\end{array}$ \\
\hline Working years, $<5$ vs. $>30$ & $\begin{array}{l}0.0369 * * \\
(2.2093)\end{array}$ & $\begin{array}{l}0.1493 * * * \\
(3.2675)\end{array}$ & $\begin{array}{l}-0.0809 * * \\
(-2.3043)\end{array}$ & $\begin{array}{l}-0.1053 * * * \\
(-3.7789)\end{array}$ \\
\hline Working years, $5-10$ vs. $>30$ & $\begin{array}{l}0.0381 * * * \\
(2.7923)\end{array}$ & $\begin{array}{l}0.1526 * * * \\
(4.0713)\end{array}$ & $\begin{array}{l}-0.0836 * * * \\
(-2.9197)\end{array}$ & $\begin{array}{l}-0.1071 * * * \\
(-4.6183)\end{array}$ \\
\hline Working years, $11-20$ vs. $>30$ & $\begin{array}{l}0.0323 * * * \\
(3.8048)\end{array}$ & $\begin{array}{l}0.1360 * * * \\
(4.9371)\end{array}$ & $\begin{array}{l}-0.0705 * * * \\
(-3.8820)\end{array}$ & $\begin{array}{l}-0.0978 * * * \\
(-5.2513)\end{array}$ \\
\hline Working years, $21-30$ vs. > 30 & $\begin{array}{l}0.0201 * * * \\
(3.3655)\end{array}$ & $\begin{array}{l}0.0947 * * * \\
(3.9606)\end{array}$ & $\begin{array}{l}-0.0421 * * * \\
(-3.3436)\end{array}$ & $\begin{array}{l}-0.0727 * * * \\
(-4.0643)\end{array}$ \\
\hline Working hours, $<8$ vs. $>32$ & $\begin{array}{l}-0.0170 \\
(-1.1315)\end{array}$ & $\begin{array}{l}-0.1028 \\
(-0.9496)\end{array}$ & $\begin{array}{l}0.0161 \\
(1.0621)\end{array}$ & $\begin{array}{l}0.1037 \\
(0.7647)\end{array}$ \\
\hline Working hours, $8-15$ vs. $>32$ & $\begin{array}{l}0.0225 * \\
(1.6452)\end{array}$ & $\begin{array}{l}0.0889 * * \\
(1.9647)\end{array}$ & $\begin{array}{l}-0.0495^{*} \\
(-1.6530)\end{array}$ & $\begin{array}{l}-0.0619 * * \\
(-2.1213)\end{array}$ \\
\hline Working hours, $16-32$ vs. $>32$ & $\begin{array}{l}0.015 * * \\
(2.405)\end{array}$ & $\begin{array}{l}0.063 * * \\
(2.43)\end{array}$ & $\begin{array}{l}-0.032 * * \\
(-2.429)\end{array}$ & $\begin{array}{l}-0.0458 * * \\
(-2.412)\end{array}$ \\
\hline Observations & 1,288 & & & \\
\hline Pseudo R-squared & 0.0429 & & & \\
\hline Wald Chi-squared & 114.03 & & & \\
\hline
\end{tabular}

Note: Robust z-statistics are reported in parentheses. The outcome of the logistic regressions is the average marginal effects $(d y / d x)$ for the discrete change in the dummy variable from 0 to 1 .

$* p<0.10, * * p<0.05, * * * p<0.01$. 
Figure 1 - Retirement planning and aggregate concerning by gender. Aggregate retirement concerns range from $\mathbf{1}=$ not concern at all to $\mathbf{5}=$ very concern

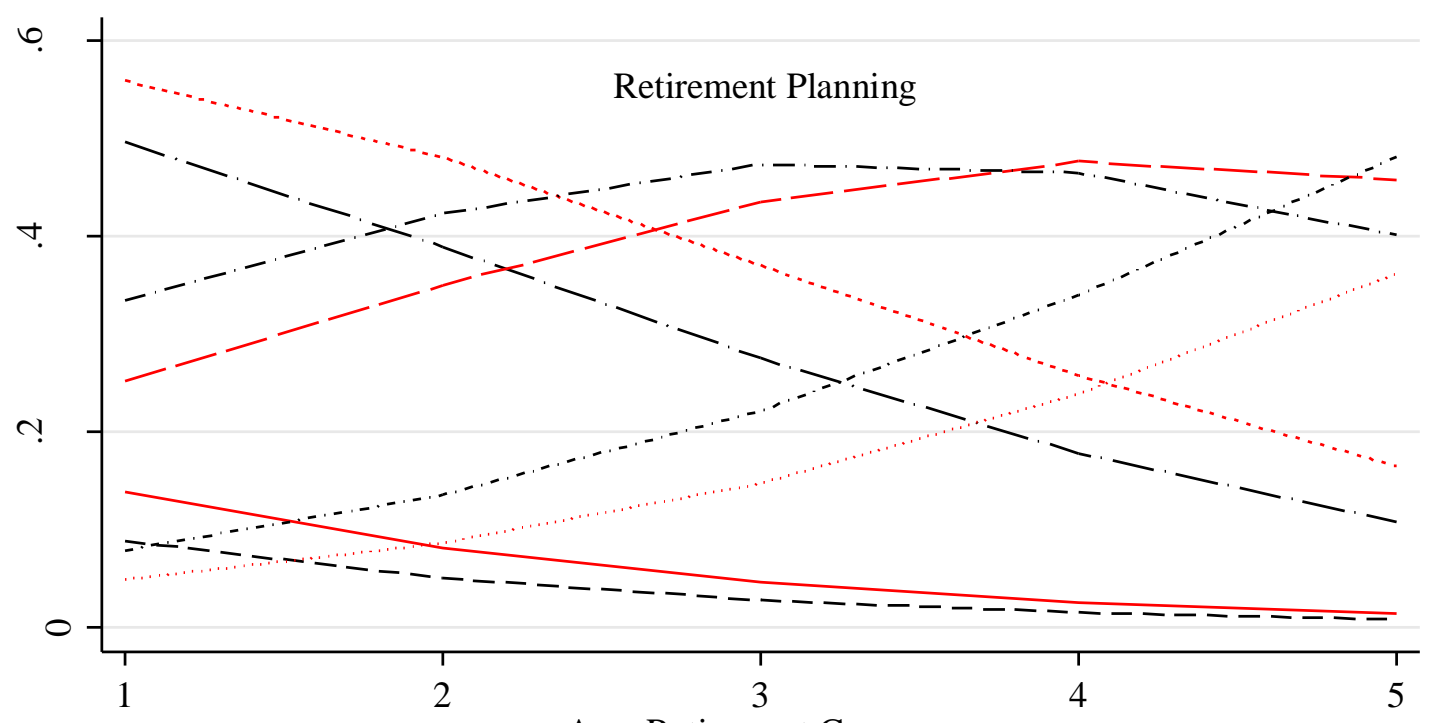

Agg. Retirement Concerns

\begin{tabular}{|c|c|c|}
\hline & $\begin{array}{l}\text { Wo-No, (almost) never } \\
\text { Wo-Yes, sometimes }\end{array}$ & $\begin{array}{l}----- \text { Men-No, (almost) never } \\
-. \text { - - Men-Yes, sometimes }\end{array}$ \\
\hline--- & Wo-Yes, regularly & $-\cdot-\cdot--$ Men-Yes, regularly \\
\hline & Wo-Yes, very often & - - - Men-Yes, very often \\
\hline
\end{tabular}

Our findings show that retirement concerns are positively correlated to the propensity to plan for retirement for those who think regularly and very often their retirement. Retirement concerns are negatively related to the propensity to plan for retirement for those who never think or sometimes their retirement. In particular, our findings indicate that income uncertainty reflected by mainly by financial concerns may prompt people to prepare more for retirement as a result of motivations related to precautionary saving.

\section{Discussion}

Limited research has investigated how uncertainty prompts people to plan their retirement and influences their post-retirement preferences by examining both financial and non-financial factors. We find that retirement concerns about financial situation and health condition are associated with a greater propensity to plan for retirement. We find no significant evidence of the influence of health conditions and loneliness on retirement planning. We find 
that aggregated retirement concerns are significantly associated with the likelihood of retirement planning. Our findings are consistent with the $\mathrm{LCH}$, i.e., that people with greater concerns will save more and thus plan their retirement to maintain the same standards of living after retirement.

Our findings highlight the influence of factors related retirement concerns on individuals' propensities to plan for retirement and on individuals' preferences regarding the ideal post-retirement situation. This study's findings have important implications for the design of policies that aim to improve individuals' post-retirement welfare. Knowledge regarding individual preferences for retirement and the factors that affect these preferences is important for both pension fund boards and policymakers who are examining solutions beyond income considerations to improve retirees' wellbeing. In particular, our findings have important implications for the design of policies that focus on increasing awareness of the social issues surrounding retirement and on employing financial literacy programs to improve financial knowledge. 


\section{References}

Ameriks, J., Caplin, A. and Leahy, J. (2002), Wealth accumulation and the propensity to plan (Working Paper No. 8920), National Bureau of Economic Research.

Attanasio, O. P. (1999), "Consumption", in Taylor, J. B. and Woodford, M. (Eds.), Handbook of Macroeconomics, Elsevier, Chapter 11.

Bayer, P.J., Bernheim, B.D. and Scholz, J.K. (2009), "The effects of financial education in the workplace: Evidence from a survey of employers", Economic Inquiry, Vol. 47, No. 4, pp. 605-624.

Bernheim, B. D. and Garrett, D. M. (2003), "The effects of financial education in the workplace: Evidence from a survey of households", Journal of Public Economics, Vol. 87, No. 7, pp. 1487-1519.

Bernheim, B. D., Garrett, D. M. and Maki, D. M. (2001), "Education and saving: The long-term effects of high school financial curriculum mandates", Journal of Public Economics, Vol. 80, No. 3, pp. 435-465.

Binswanger, J. and Carman, K. G. (2012), "How real people make long-term decisions: The case of retirement preparation", Journal of Economic Behavior \& Organization, Vol. 81, No. 1, pp. 39-60.

Browning, M. and Lusardi, A. (1996), "Household saving: Micro theories and micro facts", Journal of Economic literature, pp. 1797-1855.

Clark, R. L., Morrill, M.S. and Allen, S. G. (2012), "The role of financial literacy in determining retirement plans", Economic Inquiry, Vol. 50, No. 4, pp. 851-866.

Cook, C., Heath, F. and Thompson, R. L. (2000), "A meta-analysis of response rates in web- or internet-based surveys", Educational and psychological measurement, Vol. 60, No. 6, pp. 821-836.

Curtin, R., Presser, S. and Singer, E. (2000), "The effects of response rate changes on the index of consumer sentiment", Public Opinion Quarterly, Vol. 64, No.4, pp. 413-428.

Dvorak, T. and Hanley, H. (2010), "Financial literacy and the design of retirement plans", The Journal of Socio-Economics, Vol. 39, No. 6, pp. 645-652.

Earl, J. K., Bednall, T. C. and Muratore, A. M. (2015), "A matter of time: Why some people plan for retirement and others do not", Work, Aging and Retirement, p. wau005.

Ewisk, C. (2005), "Reform of occupational pensions in the Netherlands", De Economist, Vol. 153, No. 3, pp. 331-347.

Gollwitzer, P. M. (1996), "The volitional benefits of planning", in Gollwitzer, P. M. and Bargh, J. A. (Eds.), The psychology of action: Linking cognition and motivation to behavior, Guilford Press, New York, NY, US, pp. 287-312.

Gollwitzer, P. M. (1999), "Implementation intentions: Strong effects of simple plans", American Psychologist, Vol. 54, No. 7, pp. 493-503. 
Hershey, D. A., Henkens, K. and van Dalen, H. P. (2007), "Mapping the minds of retirement planners a cross-cultural perspective", Journal of Cross-Cultural Psychology, Vol. 38, No. 3, pp. 361-382.

Hershey, D. A., Henkens, K. and van Dalen, H. P. (2010), "What drives retirement income worries in Europe? A multilevel analysis", European Journal of Ageing, Vol. 7, No. 4, pp. 301-311.

Hershey, D. A., Jacobs-Lawson, J. M., McArdle, J.J. and Hamagami, F. (2007), "Psychological foundations of financial planning for retirement", Journal of Adult Development, Vol. 14, No. 1-2, pp. 26-36.

Hershey, D. A. and Mowen, J. C. (2000), "Psychological determinants of financial preparedness for retirement", The Gerontologist, Vol. 40, No. 6, pp. 687-697.

$\mathrm{H} \varnothing \mathrm{j}$, J. (2011), Making the Dutch Pension System Less Vulnerable to Financial Crises (OECD Economics Department Working Paper No. 832), OECD Publishing.

Holbrook, A. L., Krosnick, J. A. and Pfent, A. (2007), "The causes and consequences of response rates in surveys by the news media and government contractor survey research firms", in Lepkowski, J. M., Tucker, C., Brick, J. M., Leeuw, E. D. de, Japec, L., Lavrakas, P. J., Link, M. W., et al. (Eds.), Advances in Telephone Survey Methodology, John Wiley \& Sons, Inc., pp. 499-528.

Knoll, M. A. Z. (2010), "The role of behavioral economics and behavioral decision making in Americans' retirement savings decisions", Social Security Bulletin, Vol. 70, p. 1.

Liberman, N., Trope, Y., McCrea, S. M. and Sherman, S. J. (2007), "The effect of level of construal on the temporal distance of activity enactment", Journal of Experimental Social Psychology, Vol. 43, No. 1, pp. 143-149.

Lusardi, A. and Mitchell, O.S. (2007a), "Financial literacy and retirement preparedness: evidence and implications for financial education", Business Economics, Vol. 42, No. 1, pp. 35-44.

Lusardi, A. and Mitchell, O. S. (2007b), "Baby boomer retirement security: the roles of planning, financial literacy, and housing wealth", Journal of Monetary Economics, Vol. 54, No. 1, pp. 205-224.

Lusardi, A. and Mitchell, O. S. (2007c), "Financial literacy and retirement planning: New evidence from the rand American life panel", Michigan Retirement Research Center Research Paper No. WP, Vol. 157.

McCrea, S. M., Liberman, N., Trope, Y. and Sherman, S. J. (2008), "Construal level and procrastination", Psychological Science, Vol. 19, No. 12, pp. 1308-1314.

Muratore, A. M. and Earl, J. K. (2010), "Predicting retirement preparation through the design of a new measure", Australian Psychologist, Vol. 45, No. 2, pp. 98-111.

Owen, A. and Wu, S. (2007), "Financial shocks and worry about the future", Empirical Economics, Vol. 33, No. 3, pp. 515-530. 
Pino, A. and Yermo, J. (2010), "The impact of the 2007-2009 crisis on social security and private pension funds: A threat to their financial soundness?", International Social Security Review, Vol. 63, No. 2, pp. 5-30.

Ponds, E. H. M. and Riel, B. V. (2009), "Sharing risk: The Netherlands' new approach to pensions", Journal of Pension Economics and Finance, Vol. 8, No. 01, pp. 91105.

Van Rooij, M. C. J., Kool, C. J. M. and Prast, H. M. (2007), "Risk-return preferences in the pension domain: are people able to choose?", Journal of Public Economics, Vol. 91, No. 3-4, pp. 701-722.

Van Rooij, M. C. J., Lusardi, A. and Alessie, R. J. M. (2011), "Financial literacy and retirement planning in the Netherlands", Journal of Economic Psychology, Vol. 32, No. 4, pp. 593-608.

Van Rooij, M. C. J., Lusardi, A. and Alessie, R. J. M. (2012), "Financial literacy, retirement planning and household wealth", The Economic Journal, Vol.122, No. 560 , pp. 449-478.

Taylor, M. A. and Schaffer, M. (2012), "Planning and adaptation to retirement: The post-retirement environment, change management resources, and needoriented factors as moderators", in Wang, M. (Ed.), The Oxford Handbook of Retirement, Oxford University Press, New York, NY, US. 
This yearly series of working papers (WP) aims to publish works resulting from the scientific network of CIRIEC. The WPs are subject to a review process and are published under the responsibility of the President of the International Scientific Council, the president of the scientific Commissions or the working groups coordinators and of the editor of CIRIEC's international scientific journal, the Annals of Public and Cooperative Economics.

These contributions may be published afterwards in a scientific journal or book.

The contents of the working papers do not involve CIRIEC's responsibility but solely the author(s') one.

The submissions are to be sent to CIRIEC (ciriec@uliege.be).

Cette collection annuelle de Working Papers (WP) est destinée à accueillir des travaux issus du réseau scientifique du CIRIEC. Les WP font l'objet d'une procédure d'évaluation et sont publiés sous la responsabilité du président du Conseil scientifique international, des présidents des Commissions scientifiques ou des coordinateurs des groupes de travail et du rédacteur de la revue scientifique internationale du CIRIEC, les Annales de l'économie publique, sociale et coopérative.

Ces contributions peuvent faire l'objet d'une publication scientifique ultérieure.

Le contenu des WP n'engage en rien la responsabilité du CIRIEC mais uniquement celle du ou des auteurs.

Les soumissions sont à envoyer au CIRIEC (ciriec@uliege.be)

This working paper is indexed and available in RePEc

Ce working paper est indexé et disponible dans RePEc

ISSN 2070-8289 


\section{Publications}

2018/01 State-Owned Enterprises: Rationales for Mergers and Acquisitions Massimo FLORIO, Matteo FERRARIS \& Daniela VANDONE

2018/02 The Financial Performance, Restructuring and Privatisation of the Shipyards in the Republic of Croatia Anto BAJO, Marko PRIMORAC \& Martin HANICH

2018/03 Retirement concerns and planning of cooperative members: A study in the Dutch healthcare sector George APOSTOLAKIS \& Gert VAN DIJK 


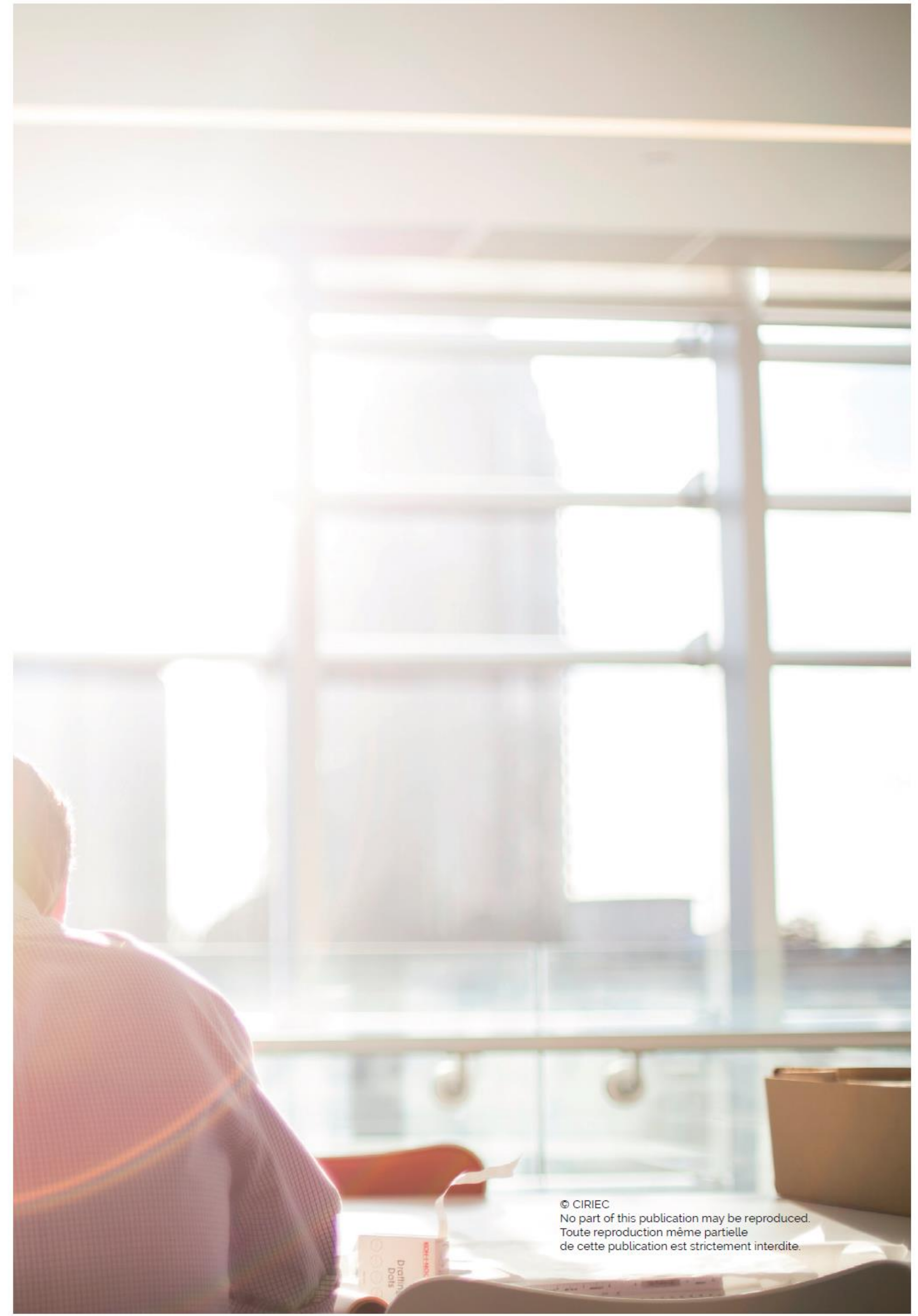


CIRIEC (International Centre of Research and Information on the Public, Social and Cooperative Economy) is a non-governmental international scientific organization.

Its objectives are to undertake and promote the collection of information, scientific research, and the publication of works on economic sectors and activities oriented towards the service of the general and collective interest: action by the State and the local and regional public authorities in economic fields (economic policy, regulation); public utilities; public and mixed enterprises at the national, regional and municipal levels; the so-called "social economy" (not-for-profit economy, cooperatives, mutuals, and non-profit organizations; etc.).

In these fields CIRIEC seeks to offer information and opportunities for mutual enrichment to practitioners and academics and for promoting international action. It develops activities of interest for both managers and researchers.

Le CIRIEC (Centre International de Recherches et d'Information sur l'Economie Publique, Sociale et Coopérative) est une organisation scientifique internationale non gouvernementale.

Ses objectifs sont d'assurer et de promouvoir la collecte d'informations, la recherche scientifique et la publication de travaux concernant les secteurs économiques et les activités orientés vers le service de l'intérêt général et collectif : l'action de l'Etat et des pouvoirs publics régionaux et locaux dans les domaines économiques (politique économique. régulation) : les services publics : les entreprises publiques et mixtes aux niveaux national, régional et local: « l'économie sociale » : coopératives, mutuelles et associations sans but lucratif : etc.

Le CIRIEC a pour but de mettre à la disposition des praticiens et des scientifiques des informations concernant ces différents domaines, de leur fournir des occasions d'enrichissement mutuel et de promouvoir une action et une réflexion internationales. Il développe des activités qui intéressent tant les gestionnaires que les chercheurs scientifiques.

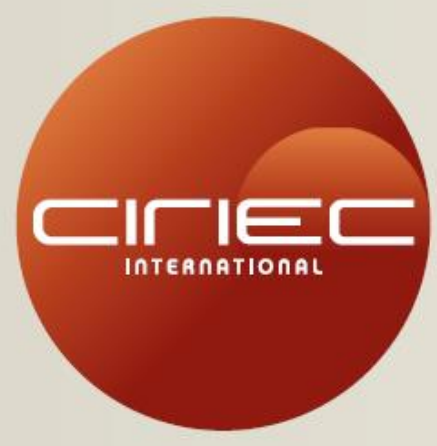

INTERNATIONAL CENTRE OF RESEARCH AND INFORMATION ON THE PUBLIC, SOCIAL AND COOPERATIVE ECONOMY-AISBL

CENTRE INTERNATIONAL DE RECHERCHES ET D'INFORMATION SUR L'ÉCONOMIE PUBLIQUE, SOCIALE ET COOPÉRATIVE - AISBL

Universite de Liège | Quartier Agora | Place des Orateurs 1 | Bātiment B33 boite 6 | BE-4000 Liege (Belgium) | T+32(0)436627 46 | F+32(0)43662958 ciriec@ulg.ac.be | www.cirieculg.ac.be 